\title{
Polskie repozytoria instytucjonalne jako miejsce dla otwartych zasobów naukowych i edukacyjnych
}

\author{
Ewa Głowacka \\ Instytut Informacji Naukowej i Bibliologii, Uniwersytet Mikołaja Kopernika w Toruniu
}

\begin{abstract}
Abstrakt
Cel/teza: Otwarte repozytoria cyfrowe to obecnie bardzo dynamicznie rozwijający się rodzaj źródeł informacji naukowej. Celem artykułu jest omówienie wyników badań nad stanem funkcjonujących w Polsce naukowych repozytoriów tworzonych przez wyższe uczelnie i inne jednostki naukowe.

Koncepcja/metody badań: Przedstawiono polskie repozytoria naukowe od strony ich rozwoju, liczebności, struktury zasobów oraz funkcji. Zdecydowano się na analizę jedynie takich inicjatyw, które gromadzą zasoby nowe, a nie - jak w przypadku licznie funkcjonujących w Polsce bibliotek cyfrowych - zdigitalizowane kolekcje dziedzictwa narodowego. Pomocą w wyborze serwisów były listy repozytoriów naukowych zawartych w portalu Uwolnij Naukę, EBIB oraz w bazie Agregator CEON. Każdy z serwisów przebadano oddzielnie. Dla przedstawienia liczby inicjatyw zagranicznych oraz funkcji repozytoriów polskich i obcych wykorzystano serwis OpenDOAR oraz literaturę przedmiotu. Wyniki i wnioski: Autorce udało się odnaleźć 33 aktualnie funkcjonujące polskie otwarte repozytoria naukowe. Ogółem zgromadziły one ok. 270 tys. różnorodnych zasobów, przede wszystkim prac dyplomowych i doktorskich, artykułów z czasopism oraz materiałów dydaktycznych. Projekty te rozwijają się bardzo aktywnie, zważywszy na to, że mają jeszcze bardzo krótką historię. Tworzenie repozytoriów przynosi wiele korzyści dla uczelni. Zaliczymy do nich wzrost jej prestiżu jako skutek wzrostu widoczności badań naukowych prowadzonych na wydziałach, promowanie kadry naukowej, wspieranie edukacji studentów poprzez ułatwienie im dostępu do materiałów dydaktycznych. Zastosowania praktyczne: Wyniki analizy polskich repozytoriów pokazują obraz ich obecnego stanu rozwoju oraz mogą stanowić zachętę do deponowania prac oraz korzystania z ich zasobów.
\end{abstract}

\section{Słowa kluczowe}

Open Access. Polskie repozytoria instytucjonalne. Polskie repozytoria dziedzinowe. Zasoby cyfrowe.

Otrzymany: 21 lipca 2016. Zrecenzowany: 20 sierpnia 2016. Zaakceptowany: 1 września 2016.

\section{Wstęp}

Współczesne przemiany w komunikacji naukowej i edukacji często rozpatrywane są w aspekcie zjawiska „Nauka 2.0”, czyli procesów oraz tendencji związanych z wykorzystaniem w nauce współczesnych technologii informacyjno-komunikacyjnych. Głównymi przejawami rozwoju zastosowań nowych technologii i nowego, bardziej otwartego spojrzenia na komunikację naukową, jest rozwój idei Open Access (OA) oraz przepływ informacji naukowej nie tylko przez tradycyjne, dotychczas rozwijane kanały (publikacje tradycyjne i elektroniczne, głównie książki i czasopisma), lecz także wykorzystanie w komunikacji naukowej 
technologii Web 2.0 i związanych z nią mediów społecznościowych (np. blogów, serwisów społecznościowych i forów internetowych). OA to ruch społeczny działający na rzecz swobodnego upowszechnienia wiedzy, który w praktyce oznacza wolny i nieograniczony dostęp do cyfrowych publikacji naukowych oraz otwarty model komunikacji naukowej.

Jedna ze strategii ruchu OA - „zielona droga” to tworzenie otwartych archiwów i repozytoriów, które gromadzą i udostępniają treści w formie cyfrowej:

Repozytorium otwarte (ang. open repository, open archive) jest to narzędzie służące zarządzaniu i długoterminowemu przechowywaniu dokumentów cyfrowych. Repozytoria wspierają rozwój badań naukowych, procesy uczenia się oraz prace administracyjne. Stosują one otwarte standardy tak, aby ich zasób był w pełni dostępny. Standardy te pozwalają na stosowanie mechanizmów, które umożliwiają importowanie, eksportowanie, przechowywanie i wyszukiwanie cyfrowych dokumentów w repozytorium. Zawartość otwartego archiwum może być bardzo różna i może służyć różnym celom oraz użytkownikom (Rychlik \& Karwasińska, b.d.).

W cyfrowych repozytoriach i archiwach mogą się znaleźć zarówno teksty niepublikowane i nierecenzowane (preprinty), jak i publikacje, które przeszły proces recenzji i zostały zaakceptowane do druku (postprinty). Repozytorium może gromadzić wszystkie formy dokumentów czy postaci danych, które powstają na uczelni: artykuły z czasopism (postprinty), rękopisy (preprinty), dane bibliograficzne, książki lub ich części, np. rozdziały, materiały konferencyjne, postery, prezentacje, prace magisterskie i doktoraty, prace habilitacyjne, materiały edukacyjne, multimedia i materiały audio-wideo, inne (Bednarek-Michalska, 2011). Obecnie rozwijane są różne typy repozytoriów, do których zaliczamy:

- repozytoria instytucjonalne (ang. institutional repository) - cyfrowe archiwa gromadzące i rozpowszechniające dorobek intelektualny konkretnej społeczności naukowej (uczelni, instytutu badawczego),

- repozytoria dziedzinowe (ang. subject repository), które gromadzą dokumenty spójne tematycznie,

- repozytoria danych badawczych (tzw. danych surowych) (ang. data repository) archiwa gromadzące surowe dane eksperymentalne, np. genomy bakterii, zwierząt czy człowieka (Rychlik \& Karwasińska, b.d.).

Repozytoria, w przeciwieństwie do czasopism, nie mają własnych recenzentów i nie finansują procesu recenzowania. Archiwa takie zazwyczaj funkcjonują przy ośrodkach akademickich lub instytucjach badawczych. Materiały gromadzi się w nich na zasadzie autoarchiwizacji (ang. self-archiving), tzn. autorzy sami deponują kopie swoich prac. Repozytoria zawierają publikowany i niepublikowany dorobek naukowy jednego lub kilku ośrodków w postaci dokumentów utworzonych jako elektroniczne (ang. born digital).

W polskiej literaturze przedmiotu polskie repozytoria otwarte kilka lat temu analizowała Emilia Karwasińska (Karwasińska, 2012) przedstawiając dziewięć takich serwisów. W niniejszym artykule omówiono działające obecnie polskie otwarte repozytoria naukowe, analizując ich rozwój, wielkość zasobów i podstawowe funkcje. Badania ukończono 23 sierpnia 2016 r. Zdecydowano się na analizę jedynie takich inicjatyw, które gromadzą zasoby nowe, a nie - jak w przypadku licznie funkcjonujących w Polsce bibliotek cyfrowych zdigitalizowane kolekcje dziedzictwa narodowego. W odnalezieniu polskich otwartych repozytoriów wykorzystano wykazy repozytoriów naukowych z portalu Uwolnij Naukę ${ }^{1}$,

\footnotetext{
${ }^{1}$ http://uwolnijnauke.pl/baza-wiedzy/
} 
$\mathrm{EBIB}^{2}$ oraz Agregatora CEON³ . Każdy z serwisów WWW repozytoriów cyfrowych przebadano oddzielnie. Dla przedstawienia liczby inicjatyw zagranicznych oraz funkcji repozytoriów polskich i obcych wykorzystano serwis Directory of Open Access Repositories $(\text { OpenDOAR })^{4}$ oraz literaturę przedmiotu. Liczbę publikacji, strukturę oraz lata powstania repozytoriów ustalano analizując ich strony WWW.

\section{Rozwój oraz funkcje repozytoriów}

Rozwój repozytoriów związany jest z procesem ewolucji systemu komunikacji naukowej w kierunku nadania znaczenia również nieformalnym, wirtualnym kanałom komunikacji. Od 2006 r. na całym świecie rośnie liczba repozytoriów OA - obecnie jest ich już ponad 3000, z czego najwięcej jest w Europie (Rys. 1) $)^{5}$.

Rys. 1. Repozytoria na świecie wg kontynentów

\section{Proportion of Repositories by Continent \\ Worldwide}

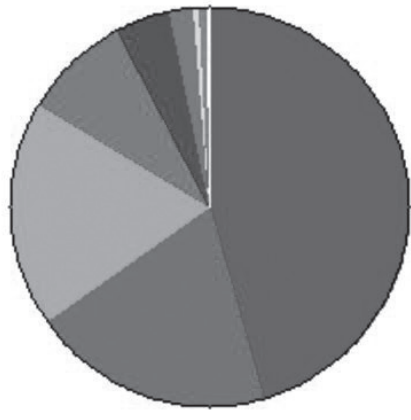

OpenDOAR 14-Sep-2016

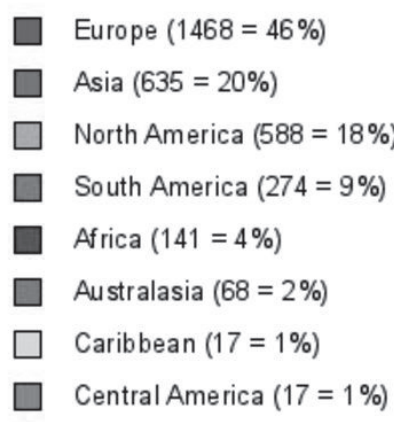

[2 Others $(4=0 \%)$ ]

Total $=3212$ repositories

Źródło: OpenDOAR, dostęp: 14.09.2016.

Repozytorium, oprócz swoich funkcji edukacyjnych, upowszechniających, archiwizujących i zabezpieczających dorobek naukowy, może być traktowane jako platforma wydawnicza, daje ono bowiem możliwość archiwizowania kolekcji czasopism uczelnianych. Ciekawym zjawiskiem jest też wydawanie czasopism-nakładek (ang. overlay journals) bazujących na zasobie repozytorium. Jest to wysokiej jakości czasopismo Open Access, którego zasób znajduje się w jednym lub większej liczbie repozytoriów. Selekcjonuje ono

\footnotetext{
2 http://www.ebib.pl/?page_id=673

${ }^{3}$ http://agregator.ceon.pl/

${ }^{4}$ http://www.opendoar.org/

${ }^{5}$ Katalog OpenDOAR rejestruje repozytoria otwarte, ale również biblioteki cyfrowe gromadzące dziedzictwo kulturowe.
} 
teksty dostępne w otwartym trybie. Bywa też tak, że część czasopism posiada zasób wydany głównie przez komercyjnych wydawców z odsyłaczami do pełnych tekstów zarchiwizowanych w repozytoriach w formie pre- lub postprintu. Przykładem czasopisma nakładki jest Lund Medical Faculty Monthly, które gromadzi artykuły z czasopism komercyjnych publikowane przez autorów Wydziału Medycznego na Lund University. Część uczelnianych repozytoriów tworzy dodatkowe usługi służące promocji naukowców. Jedną z nich jest tzw. e-portfolio, które daje możliwość umieszczenia swojego profilu w repozytorium. W jednym miejscu umieszczane są informacje o autorze (np. życiorys naukowy), prezentowane są publikacje naukowe, oraz popularnonaukowe, zdobyte granty, nagrody oraz zainteresowania naukowe. Takie usługi świadczą np. University of Rochester, Bond University oraz Digital Academic Repository Universiteit van Amsterdam (Rychlik, 2011, 12).

W wielu krajach istnieją instytucje koordynujące budowanie systemów informacyjnych nie tylko dla nauki, ale także dla edukacji. Przykładem bardzo dobrej praktyki w tym zakresie jest Wielka Brytania i działający w tym kraju Joint Information Systems Committee (JISC). Komitet JISC przeprowadził wiele badań związanych z Open Access, w tym także na temat modeli narodowych platform naukowych. W wyniku tych badań wyróżniono trzy rozwiązania(Bednarek-Michalska, 2011):

- model scentralizowany - metadane i zasoby są gromadzone w jednym miejscu,

- model rozproszony - istnieje wiele instytucjonalnych repozytoriów oraz wspólna wyszukiwarka,

- model agregacyjny lub hybrydowy - zasoby są gromadzone w różnych miejscach, ale metadane są agregowane w centralnej bazie danych i tam następuje proces wyszukiwania i ujednolicania zasobu.

Współcześnie tworzone są też narodowe portale zapewniające dostęp do zasobów naukowych, np. holenderski projekt NARCIS - The gateway to scholarly information in The Netherlands ${ }^{6}$ lub HAL ${ }^{7}$ - wielodziedzinowe archiwum francuskie (Bednarek-Michalska, 2011, 51).

Przedstawiciele nauk ścisłych coraz częściej postulują rozszerzenie Open Access o udostępnianie w repozytoriach nie tylko artykułów, lecz również danych badawczych, co może znacząco wpłynąć na postęp naukowy. Powstają więc repozytoria danych badawczych (tzw. danych surowych) Tworzone przez wielkie konsorcja instytucji naukowych, centra badawcze a czasem biblioteki uniwersyteckie. Obecny system publikacji nie sprzyja upowszechnianiu danych, również sami naukowcy niechętnie je udostępniają. Dostępność danych jest także ograniczana przez uwarunkowania prawne oraz czynniki ekonomiczne i techniczne. Brak odpowiednich standardów publikacji surowych danych powoduje również, że ich gromadzenie, przetwarzanie i agregowanie jest utrudnione. W 2009 r. w Londynie podczas spotkania przedstawicieli British Library, Technical Information Center of Denmark, TU Delft Library, National Research Council's Canada Institute for Scientific and Technical Information (NRC-CISTI), California Digital Library, Purdue University oraz German National Library of Science and Technology postanowiono utworzyć stowarzyszenie zajmujące się upowszechnianiem informacji o danych badawczych. Pierwszym wykazem repozytoriów danych badawczych był serwis internetowy DataCite ${ }^{8}$ (Bednarek-Michalska, 2012).

\footnotetext{
${ }^{6}$ http://www.narcis.nl/

${ }^{7} \mathrm{http} / / /$ hal.archives-ouvertes.fr/

${ }^{8}$ http://www.datacite.org/
} 


\section{Polskie otwarte repozytoria naukowe}

Autorce udało się ustalić, że w Polsce obecnie funkcjonują 33 otwarte repozytoria cyfrowe (Tab. 1). Mają one charakter archiwów gromadzących dorobek jednej uczelni, bądź wybranych jednostek naukowych uczelni wyższych i innych instytucji naukowych. Udostępniają materiały dydaktyczne oraz dorobek naukowy pracowników i doktorantów. Ich struktura odwzorowuje strukturę uczelni. Wyjątkiem jest Repozytorium UW, które gromadzi tylko rozprawy doktorskie. Materiały edukacyjne są udostępniane w ramach kolekcji wydziałowych w osobnych podkolekcjach. Ten rodzaj kolekcji cyfrowych rozwija się w Polsce bardzo aktywnie, zważywszy na to, że mają jeszcze krótką historię - pierwsze (repozytorium PCSS) powstało w 2006 r., ale najwięcej tego typu projektów zaczęto rozwijać w latach 2012-2013.

Tabela 1. Polskie otwarte repozytoria naukowe (stan na 23.08.2016)

\begin{tabular}{|l|c|c|}
\hline \multicolumn{1}{|c|}{ Nazwa repozytorium } & $\begin{array}{c}\text { Liczba } \\
\text { publikacji }\end{array}$ & $\begin{array}{c}\text { Rok } \\
\text { powstania }\end{array}$ \\
\hline \multicolumn{1}{|c|}{$\mathbf{1}$} & $\mathbf{2}$ & $\mathbf{3}$ \\
\hline $\begin{array}{l}\text { Repozytorium Cyfrowe Instytutów Naukowych Polskiej Akademii } \\
\text { Nauk (RCIN) }\end{array}$ & 58566 & 2008 \\
\hline Repozytorium Politechniki Warszawskiej & $57170^{*}$ & 2013 \\
\hline Repozytorium Uniwersytetu Jagiellońskiego & 28404 & 2015 \\
\hline Repozytorium Uniwersytetu Łódzkiego (RUŁ) & 16819 & 2011 \\
\hline Repozytorium Uniwersytetu A. Mickiewicza (AMUR) & 12939 & 2009 \\
\hline Repozytorium Politechniki Krakowskiej (SUW) & 8151 & 2009 \\
\hline Repozytorium Centrum Otwartej Nauki (CEON) & 8727 & 2012 \\
\hline $\begin{array}{l}\text { Repozytorium Krakowskiej Akademii im. A.F. Modrzewskiego } \\
\text { (eRIKA) }\end{array}$ & 7283 & 2013 \\
\hline Repozytorium Uniwersytetu Ekonomicznego we Wrocławiu (WIR) & 7264 & 2014 \\
\hline Repozytorium Akademii Wychowania Fizycznego w Warszawie & 4368 & b.d. \\
\hline Repozytorium Uniwersytetu w Białymstoku (RUB) & 3928 & 2013 \\
\hline Repozytorium Uniwersytetu M. Kopernika w Toruniu (RUMAK) & 3490 & 2012 \\
\hline Repozytorium Uniwersytetu im. Kazimierza Wielkiego & 3292 & 2013 \\
\hline Repozytorium Politechniki Poznańskiej & 1293 & 2011 \\
\hline Repozytorium Uniwersytetu Rzeszowskiego & 1280 & 2013 \\
\hline Repozytorium Uniwersytetu Wrocławskiego & 1237 & 2013 \\
\hline Repozytorium Politechniki Łódzkiej (Cyrena) & 1121 & 2015 \\
\hline Repozytorium Uniwersytetu Warszawskiego & 1051 & 2012 \\
\hline $\begin{array}{l}\text { Repozytorium Uniwersytetu Techniczno-Przyrodniczego w Byd- } \\
\text { goszczy }\end{array}$ & 918 & 2011 \\
\hline Repozytorium Wiedzy Politechniki Wrocławskiej (SUW) & 913 & 2014 \\
\hline Biblioteka Cyfrowa Uniwersytetu Papieskiego Jana Pawła II & 910 & 2013 \\
\hline
\end{tabular}




\begin{tabular}{|l|c|c|}
\hline \multicolumn{1}{|c|}{$\mathbf{1}$} & $\mathbf{2}$ & $\mathbf{3}$ \\
\hline Repozytorium UP w Krakowie & 848 & b.d. \\
\hline Repozytorium WSB-NLU & 812 & 2013 \\
\hline Repozytorium IBB PAN & 640 & 2010 \\
\hline Repozytorium Instytucjonalne PCSS & 640 & 2006 \\
\hline Repozytorium Instytutu Medycyny Pracy w Łodzi (ECNIS) & 601 & b.d. \\
\hline $\begin{array}{l}\text { Repozytorium Uniwersytetu Przyrodniczo-Humanistycznego } \\
\text { w Siedlcach }\end{array}$ & 556 & 2015 \\
\hline $\begin{array}{l}\text { Repozytorium Wydziału Elektrycznego Politechniki Wrocławskiej } \\
\text { (ENY) }\end{array}$ & 430 & 2008 \\
\hline Biblioteka Cyfrowa Katedry Lingwistyki Formalnej UW & 387 & 2008 \\
\hline Repozytorium Publikacji Naukowych Politechniki Śląskiej (Repolis) & 353 & 2012 \\
\hline \begin{tabular}{l} 
Otwarte Repozytorium Nauk Historycznych (Lectorium) \\
\hline Repozytorium Dolnośląskiej Szkoły Wyższej (oPUB)
\end{tabular} & 257 & 2014 \\
\hline $\begin{array}{l}\text { Repozytorium Polsko-Japońskiej Wyższej Szkoły Technik Kompu- } \\
\text { terowych }\end{array}$ & 177 & 2014 \\
\hline $\begin{array}{l}\text { * Baza wiedzy PW liczy 104823 obiektów, takich jak publikacje, opisy projektów, wydarzeń, profile } \\
\text { naukowców. Samych publikacji jest 57 170. }\end{array}$ & b.d. \\
\hline
\end{tabular}

Źródło: Opracowanie własne na podstawie analizy danych z portalu Uwolnij Naukę, Agregatora CEON oraz witryn repozytoriów.

\subsection{Repozytoria gromadzqce dorobek pracowników i studentów pojedynczych uczelni}

Obecnie największą tego typu inicjatywą jest Repozytorium Politechniki Warszawskiej, które stanowi integralną część systemu Bazy Wiedzy PW. W repozytorium archiwizuje się w wersji cyfrowej pełne teksty materiałów dokumentujących prowadzone prace, w tym: monografie, artykuły z czasopism, rozdziały z książek i raporty, patenty, a także teksty utworów stanowiących podstawę do nadawania stopni i tytułów naukowych, prace licencjackie i magisterskie, projekty badawcze. Repozytorium działa od 2013 r. Koncepcja i projekt techniczny oraz oprogramowanie Bazy Wiedzy PW - OMEGA-PSIR zrealizowane zostały na Wydziale Elektroniki i Technik Informacyjnych PW w ramach projektu SYNAT 9 . Do dużych inicjatyw tego rodzaju należy również Repozytorium Uniwersytetu Łódzkiego (RUŁ), które zajęło czwarte miejsce wg międzynarodowego Ranking Web of Repositories ${ }^{10}$ w kategorii repozytoriów polskich oraz pierwsze miejsce na liście Agregatora Centrum Otwartej Nauki $(\mathrm{CEON})^{11}$ w kategorii repozytoriów o największej liczbie dokumentów. Jednym z pierwszych, wzorcowych i bogatych w zasoby repozytoriów instytucjonalnych jest

\footnotetext{
9 Projekt był realizowany w Polsce w okresie 08.2010-08.2013. Jego celem było utworzenie platformy dla sieciowych zasobów wiedzy dla nauki, edukacji.

${ }^{10}$ http://repositories.webometrics.info/, stan na lipiec 2016

11 Informacja ze strony repozytorium RUŁ, http://repozytorium.uni.lodz.pl
} 
też utworzone w 2009 r. Repozytorium Uniwersytetu im. Adama Mickiewicza - AMUR. Według wspomnianego rankingu Ranking Web of World Repositories, repozytorium AMUR zajęło 287 miejsce wśród najlepszych repozytoriów na świecie. Te cztery projekty są najzasobniejsze w dokumenty spośród polskich repozytoriów pojedynczych instytucji, jednak liczba materiałów cyfrowych zgromadzonych w Repozytorium PW jest kilkakrotnie większa niż wszystko, co udostępniono w ramach trzech pozostałych inicjatyw.

Kolejną grupę projektów stanowią archiwa liczące kilka tysięcy zbiorów. Największe z nich to Repozytorium Politechniki Krakowskiej (RPK) udostępniające zasoby naukowe oraz dydaktyczne autorstwa pracowników i studentów PK, a także publikacje wydawane przez wydawnictwo uczelni oraz cyfrowe wersje zbiorów Biblioteki Politechniki Krakowskiej (BPK). Następne pod względem liczebności zasobów są Repozytorium Krakowskiej Akademii im. Andrzeja Frycza Modrzewskiego (eRIKA) oraz zapoczątkowane w 2014 r. Repozytorium Uniwersytetu Ekonomicznego we Wrocławiu (WIR), które udostępniają już ok. 8 tys. publikacji. Mniej więcej o połowę mniej zasobów udostępnia Repozytorium Akademii Wychowania Fizycznego w Warszawie, Repozytorium Uniwersytetu w Białymstoku, Repozytorium UKW, a także Repozytorium Uniwersytetu Mikołaja Kopernika w Toruniu - RUMAK. Prawie wszystkie powstały w latach 2012-2013 i rozwijają się w podobnym tempie - kolekcja każdego z nich liczy ok. 3 tys. dokumentów, oprócz inicjatywy warszawskiej AWF udostępniającej ponad 4300 publikacji. Z kolei projektem koordynowanym przez UW oraz Interdyscyplinarne Centrum Modelowania Matematycznego i Komputerowego (ICM), a więc również służącym całej uczelni, jest Repozytorium Uniwersytetu Warszawskiego (RUW). Jednak inicjatywa ta, jak już wspomniano, ogranicza swoją działalność tylko do udostępniania kolekcji rozpraw doktorskich. W przyszłości twórcy RUW zamierzają rozszerzyć jego zasób o inne materiały (artykuły, książki, materiały dydaktyczne i pokonferencyjne $)^{12}$.

Do grupy repozytoriów instytucjonalnych o mniejszych kolekcjach (ok. 1000) zaliczają się: Uniwersytetu Jagiellońskiego, Uniwersytetu Techniczno-Przyrodniczego w Bydgoszczy, Uniwersytetu Wrocławskiego, Wyższa Szkoła Biznesu - National-Louis University w Nowym Sączu (WSB-NLU) - uwzględniono w niej również uczelnie partnerskie (Sidor, 2014), Repozytorium Publikacji Naukowych Politechniki Śląskiej, Uniwersytetu Przyrodniczo-Humanistycznego w Siedlcach, Dolnośląskiej Szkoły Wyższej oPUB, Polsko-Japońskiej Wyższej Szkoły Technik Komputerowych oraz Biblioteka Cyfrowa Uniwersytetu Papieskiego Jana Pawła II. Bogatym w zasoby jest Repozytorium Uniwersytetu Jagiellońskiego. Liczy obecnie ponad 28 tys. pozycji, jednak przeważającą część tej kolekcji stanowi bibliografia prac pracowników uczelni, która z czasem będzie uzupełniana o pełne teksty publikacji. Publikacje pełnotekstowe udostępniane są w odrębnym dziale Zasoby repozytorium, który w sierpniu 2016 r. liczył nieco ponad 1000 pozycji.

Obok repozytoriów instytucjonalnych, które powstają na wyższych uczelniach dla wszystkich ich jednostek, w Polsce tworzone są odrębne kolekcje cyfrowe dla poszczególnych instytutów naukowych i badawczych. W 2006 r. powstało Repozytorium Poznańskiego Centrum Superkomputerowo-Sieciowego (PCSS). Znajduje się w nim 640 publikacji dotyczących m.in. systemu dLibra, usług sieciowych, tworzenia środowiska informatycznego bibliotek cyfrowych. Do repozytoriów obejmujących prace jednego wydziału

${ }^{12}$ Repozytorium Uniwersytetu Warszawskiego, http://depotuw.ceon.pl/browse?type=title 
należy uruchomiona w 2008 r. Biblioteka Cyfrowa Katedry Lingwistyki Formalnej UW. Do omawianej grupy zalicza się również Repozytorium Wydziału Elektrycznego Politechniki Wrocławskiej (ENY)oraz Repozytorium Instytutu Biochemii i Biofizyki PAN (IBB PAS) ${ }^{13}$. W Polsce funkcjonuje też Repozytorium Instytutu Medycyny Pracy w Łodzi (ECNIS). Zbiory wymienionych repozytoriów nie przekraczają kilkuset pozycji.

\subsection{Repozytoria wspóttworzone przez wiele instytucji}

Obok repozytoriów instytucjonalnych, które są prowadzone przez pojedyncze instytucje w Polsce obecne są również kolekcje cyfrowe, które obejmują zespoły zasobów kilku lub kilkunastu różnych instytucji naukowych. Obecnie funkcjonuje kilka takich repozytoriów, z czego jedno wpisuje się w szerszą inicjatywę międzynarodową.

Do tej grupy repozytoriów należy Repozytorium Cyfrowe Instytutów Naukowych Polskiej Akademii Nauk (RCIN). Założeniem projektu jest utworzenie ponadregionalnego i multidyscyplinarnego repozytorium cyfrowego złożonego ze zdigitalizowanych materiałów archiwalnych, publikacji naukowych, dokumentacji badań oraz piśmienniczego dziedzictwa kulturowego wyselekcjonowanych ze zbiorów 16 polskich instytutów naukowych oraz ich bibliotek tworzących Konsorcjum (RCIN, 2014). RCIN funkcjonuje od 2008 r. i obecnie daje dostęp do ok. 60 tys. dokumentów.

Sieć Doskonałości ECNIS ${ }^{14}$ (Environmental Cancer Risk, Nutrition and Individual Susceptibility - Rak Środowiskowy, Dieta i Indywidualna Wrażliwość) rozpoczęła działalność w 2005 r. w ramach Szóstego Programu Ramowego Badań i Rozwoju Unii Europejskiej. Zrzesza ona przedstawicieli europejskich ośrodków naukowych zajmujących się badaniami nad rakiem środowiskowym z 13 krajów (Belgia, Dania, Finlandia, Grecja, Holandia, Hiszpania, Francja, Niemcy, Polska, Szwecja, Węgry, Wielka Brytania, Włochy). Celem jej założycieli było stworzenie trwałej struktury instytucji partnerskich, umożliwiającej prowadzenie wspólnych badań nad rakiem. Wśród uczestników programu w 2007 r. powstała idea budowania otwartego repozytorium dziedzinowego zawierającego dokumenty będące wynikiem wykonanych prac. Koordynatorem działań sieci jest Instytut Medycyny Pracy (IMP) w Łodzi, a Bibliotece Naukowej IMP powierzono zadania związane z administrowaniem repozytorium (Przyłuska et al., 2007). Repozytorium ECNIS jest otwartym archiwum dokumentów, daje możliwość zamieszczania pre- i postprintów, raportów i prezentacji oraz wyników badań i materiałów źródłowych. Celem utworzenia repozytorium ECNIS było jak najszybsze archiwizowanie prac naukowych i udostępnianie ich szerokiej opinii publicznej. System wykorzystuje najnowsze zasady udostępniania pełnych tekstów dokumentów, posiada funkcję autoarchiwizacji, system alertów o nowych publikacjach, pozwala na tworzenie bezpośrednich połączeń do serwisów społecznościowych typu Connotea, Delicious, Citeulike, Facebook, zakładanie indywidualnych stron dla autorów, które informują o zainteresowaniach badawczych i dorobku publikacyjnym. Wpisuje się tym samym w nurt przemian otwartości w komunikacji naukowej. Jest pierwszym repozytorium tego typu budowanym przez polskie biblioteki (Przyłuska \& Radomska, 2010).

\footnotetext{
${ }^{13}$ W sierpniu 2016 r. strona była nieaktywna.

14 ECNIS, http://ecnis.openrepository.com/ecnis/
} 
Instytucje naukowe, które nie prowadzą własnego repozytorium, mogą skorzystać z Repozytorium CEON (Repozytorium Centrum Otwartej Nauki) prowadzonego przez ICM UW. W tym repozytorium prace mogą zamieszczać, przechowywać i publicznie udostępniać wyłącznie zarejestrowani autorzy będący osobami fizycznymi. We współpracy z Biblioteką Uniwersytecką w Warszawie CEON prowadzi również repozytorium UW. W Archiwum CEON prezentowana jest też kolekcja wybranych książek z zakresu humanistyki i nauk społecznych, zdigitalizowaną w 2007 r. oraz serwis „Otwórz książkę”. Jest to cyfrowa kolekcja współczesnych książek naukowych,w której skład wchodzą przede wszystkim książki niedostępne w wersji drukowanej, poszukiwane ze względu na wartość naukową i edukacyjną. Obecnie serwis udostępnia ponad 300 tytułów, przede wszystkim z nauk społecznych (socjologia, psychologia, ekonomia i in.) oraz humanistycznych (historia, kulturoznawstwo, literaturoznawstwo $)^{15}$.

Dla nauk humanistycznych powstaje od 2014 r. repozytorium dziedzinowe - Lectorium (Otwarte Repozytorium Nauk Historycznych) ${ }^{16}$. Materiały prezentowane są w sześciu głównych działach tematycznych: historia, archeologia, historia sztuki, bibliologia i informacja naukowa, etnologia i antropologia kulturowa oraz muzykologia. Lectorium jest wspólnym projektem Wydziału Historycznego Uniwersytetu Warszawskiego oraz ICM UW.

W Polsce działa też Agregator Centrum Otwartej Nauki ${ }^{17}$. Jest to wspólny punkt dostępu do zasobów polskich otwartych repozytoriów. Zapewnia ich większą widoczność, szerszą dostępność i łatwiejsze wyszukiwanie. Pozwala na przeszukiwanie polskich repozytoriów wg tytułu, daty publikacji, języka i typu. Niestety, nie wszystkie archiwa są w nim zarejestrowane. Aktualnie (sierpień 2016 r.) agregator rejestruje 19 repozytoriów i ok. 65 tys. pozycji. Agregator nie rejestruje zbiorów kilkunastu polskich zasobów tego rodzaju. Dobrym źródłem informacji o polskich repozytoriach otwartych jest też baza wiedzy serwisu Uwolnij Naukę zawierająca obszerną listę (31 pozycji) takich projektów.

\section{Podsumowanie}

Obecnie otwarte repozytoria w Polsce zgromadziły ok. 27 tys. różnorodnych zasobów, przede wszystkim prac dyplomowych i doktorskich, artykułów z czasopism oraz materiałów dydaktycznych. Omawiane projekty rozwijają się bardzo aktywnie, zważywszy na ich krótką historię. Tworzone są przez uczelnie publiczne i niepubliczne, stanowią efekt wspólnych inicjatyw różnych jednostek naukowych bądź są projektami pojedynczych instytutów naukowo-badawczych. Ich liczba stale rośnie. Większość z nich wykorzystuje oprogramowanie Open Source, szczególnie Dspace i EPrints. Część z nich funkcjonuje na specjalnie utworzonych własnych platformach informatycznych. Często wykorzystywane jest oprogramowanie dLibra.

Do zasobów repozytoriów można przekazywać materiały, do których prawa należą do naukowców lub ich rodzimych instytutów (np.: sprawozdania, raporty, analizy, wyniki badań, publikacje wydawnictw uczelnianych). W przypadku opublikowania pracy u komercyjnego wydawcy należy upewnić się czy posiada się prawo do zamieszczenia jej w repozytorium.

\footnotetext{
15 Otwórz książkę, http://otworzksiazke.pl

16 Lectorium, http://lectorium.edu.pl/pl/

17 Agregator CEON, http://agregator.ceon.pl/
} 
Pomocą może służyć portal SHERPA, w którym znajdują się informacje o warunkach umieszczania w repozytoriach materiałów, opublikowanych wcześniej u danego wydawcy. Zasady przestrzegania prawa autorskiego powinny być opisane i udostępnione na platformie repozytorium (Rychlik \& Karwasińska, b.d.).

Tworzenie repozytoriów przynosi wiele korzyści dla uczelni. Należą do nich m.in. wzrost jej prestiżu jako skutek zwiększenia widoczności w sieci wyników badań naukowych prowadzonych na wydziałach, promowanie kadry naukowej, wspieranie edukacji studentów poprzez ułatwienie im dostępu do materiałów dydaktycznych. Autorzy deponujący prace w otwartych repozytoriach mogą również zaobserwować różne korzyści z tego faktu, np. wzrost cytowalności prac umieszczonych w otwartym dostępie, zwiększenie „widoczności” w sieci dorobku naukowego - prace umieszczane w repozytoriach są indeksowane przez światowe wyszukiwarki np. Google Scholar, powszechność i szybkość dostępu do badań oraz możliwość utworzenia cyfrowego CV - prezentacja własnego dorobku z dostępem do pełnych tekstów. Coraz powszechniej obiektem zainteresowania są tzw. dane surowe (ang. raw data), czyli dane badawcze przetworzone w niewielkim stopniu, np. dokumenty finansowe, filmy, fotografie, nagrania audio, notatki, pamiętniki, rysunki, statystyki demograficzne i ekonomiczne, itp. Tak rozumiane dane przeciwstawione są opracowaniom, czyli tradycyjnym publikacjom naukowym, fachowym, publicystycznym, jak artykuły, eseje, książki, podręczniki, raporty, referaty. Powstaje coraz więcej archiwów surowych danych, co pozwala na wielokrotne wykorzystanie tych samych danych w wielu badaniach. Jest to jednak temat na odrębne opracowanie.

\section{Bibliografia}

Bednarek-Michalska, B. (2011). Rola bibliotek naukowych we wdrażaniu rozwiazań otwartych. Repozytorium Open Access - model dla uczelni [online]. [19.05. 2016], http://suw.biblos.pk.edu.pl/ resources/i5/i7/i8/i0/r5780/BednarekMichalskaB_RolaBibliotek.pdf

Bednarek-Michalska, B.(2012) Repozytoria surowych danych - dlaczego biblioteki powinny je znać? [online]. Biuletyn EBIB, 135,[20.11.2015], http://www.nowyebib.info/images/stories/numery/135/135_michalska_.pdf

Karwasińska, E. (2012). Polskie repozytoria otwarte. [online] Biuletyn EBIB, 20.08.2016], http://open. ebib.pl/ojs/index.php/ebib/article/view/157/296

Przyłuska J.; Radomska, A. (2010). Repozytorium tematyczne publikacji powstałych w ramach sieci doskonałości ECNIS [online]. Forum Bibl. Med., 1(5), [29.08.2016], http://cybra.lodz.pl/Content/4644

Przyłuska J.; Radomska, A.; Kłosiński, R. (2007). Budowanie repozytorium dziedzinowego - doświadczenia Biblioteki Naukowej Instytutu Medycyny Pracy w Łodzi i Biblioteki Politechniki Łódzkiej [online]. W: EBIB Materiaty konferencyjne $n r$ 18. [29.08.2016], http://www.ebib.pl/publikacje/ matkonf/mat18/przyluska_radomska_klosinski.php

RCIN (2014). Informacje o Projekcie RCIN [online], [29.08.2016], http://www.rcin.org.pl/dlibra/ text?id=aboutRCIN

Rychlik, M.; Karwasińska, E. (b.d.). Repozytoria otwarte - zielony kanat Open Access [online]. [24.08.2016], http://elearning.pwste.edu.pl $/$ moodle/mod/book/view.php?id=93\&chapterid=28 Rychlik M. (2011). Co repozytorium instytucjonalne oferuje swojej społeczności akademickiej? - na przykładzie repozytorium AMUR oraz repozytoriów na świecie [online]. [29.08.2016], http://fbc. pionier.net.pl/details/nn2Zvh5

Sidor, M. (2014). Repozytorium instytucjonalne - jego funkcje i narzędzia w komunikacji naukowej w oparciu o doświadczenia WSB - [Preprint] [on-line]. [29.08.2016], http://repozytorium.wsb-nlu. edu.pl/handle/11199/4384 


\title{
Polish Institutional Repositories as a Place for Open Scientific and Educational Resources
}

\begin{abstract}
Purpose/Thesis: Open digital repositories are rapidly developing type of information sources for science and education. The aim of this article is to discuss the results of research on the current state of digital repositories maintained by universities and other research institutions in Poland.

Approach/Research methods: Polish digital repositories were described in terms of their current state of development, abundance, structure, collections and functions. It was decided to analyze only the digital collections recording new resources, and not - as in the case of many digital libraries in Poland - digitized collections of national heritage. The repositories in question were selected based on the list of repositories from the following web portals: Uwolnij Naukę, EBIB and CEON database aggregator. Each website was analyzed individually. Data from OpenDOAR was used to present some statistical background for this type of projects in Poland.

Results and conclusions: The author found 33 currently available open digital repositories in Poland. They provide access to approximately 270,000 resources of various types, mostly theses and dissertations, journal articles and teaching materials. Open digital repositories are developing very actively, given that they have a very short history. Creating and maintaining digital repositories by the universities brings many benefits such as leveraging reputation as a result of increased visibility of the scientific research conducted at the departments, promoting the academic staff, supporting the students by facilitating their access to teaching materials.

Originality/Value: The results of the analysis of Polish digital repositories shows their current state of development and may encourage researchers to deposit their works there and use repository resources in their research process.
\end{abstract}

\section{Keywords}

Open Access. Polish institutional repositories. Polish domain repositories. Digital resources.

Dr hab. EWA GEOWACKA pracuje w Instytucie Informacji Naukowej i Bibliologii UMK. Obecnie jest jego dyrektorem. Jej zainteresowania badawcze koncentruja się wokót elektronicznych zasobów informacji, zarzadzania jakościa i ocena jakości zasobów informacyjnych, zarzadzania informacja, zarzadzania wiedza, architektury informacji.

Kontakt $z$ autorka:

egt@umk.pl

Instytut Informacji Naukowej i Bibliologii, Uniwersytet Mikołaja Kopernika w Toruniu

ul. Władysława Bojarskiego 1

87-100 Toruń 